\title{
Microbiology as a Resource for Health Promotion
}

\author{
Luiz Paulo Lessa \\ Institute of Microbiology Paulo de Goes \\ Federal University of Rio de Janeiro - UFRJ \\ Rio de Janeiro, Brazil \\ Gabriel Frazao Silva Pedrosa \\ Master's degree in Physical Education \\ Federal University of Rio de Janeiro -UFRJ \\ Rio de Janeiro, Brazil \\ Luciana Nunes Prado Carneiro \\ Degree in Biological Sciences \\ Paulista University
}

\author{
Natalia Rangel Metzker \\ Degree in Biological Sciences \\ Paulista University \\ Gabriel Caldas da Costa \\ Degree in Biological Sciences \\ Amazonas State University \\ Criciane Melo Sousa \\ Degree in Natural Sciences - Biology \\ Federal University of Maranhão \\ Maria Alice Costa da Silva \\ Master in Ecosystem Ecology \\ University of Vila Velha
}

\begin{abstract}
Health education is a valuable health promotion tool that provides individuals with conscious decision-making in their healthy way of living. The aim of this study is to describe characteristics of the reality of actions of an extension project. Its methodology is characterized as a descriptive research. The way of obtaining the data occurred from the perceptions of the members of the extension project. A didactic game was elaborated by means of pairs of cards that represented certain diseases and their possible causes. Working with games, among other games, allows new forms of language to be learned by children. More actions of this kind can be encouraged, since they allow extremely relevant gains in the social, political and economic scenario of a region.
\end{abstract}

Keywords:- Microbiology; Experience report; Games and Toys.

\section{INTRODUCTION}

There are always concomitances in teaching and the way of teaching. Learning occurs between varied teachings that, inevitably, are inserted in people's daily lives and that will enhance development processes in the most diverse phases of life. [1]

It is commonly agreed that the understanding of learning through play enables a favorable growth and development of the child. Playful activities tend to provide improvement in the functions of psychic abilities, with reflexes in personality formation. [2]

Recreational activities bring numerous contributions to the child's cognitive development. Among them, the development of skills, attitudes, and forms of interpersonal relationships obtained through respect, cooperation, autonomy and socialization. [2]
Health education is a valuable health promotion tool that acts in a participatory way so that the individual obtains the necessary knowledge for decision-making in a conscious way in his/her healthy way of living and in his/her healthdisease process. [3]

The absence of hygiene habits can trigger the emergence of several pathologies, whether personal or collective. Sanitary treatment is of a collective hygiene order, for example. When there is no proper treatment, water and sewage, some infectious diseases can affect the population. [4]

Children are considered to be more vulnerable to the environment and, consequently, to contamination susceptible to the environment. In Brazil, in recent years there has been a decrease in cases of infant mortality, due to the factors of improvements in environmental sanitation. This reduction is undeniable, however, it is not distributed homogeneously, with inequalities in the most diverse population segments. [5]

Based on the assumption, this is the problem of this research: how can the teaching of hygiene practices, through didactic games, contribute to the decrease in the emergence of infectious diseases in children?

The aim of this study is to describe characteristics of the reality of actions of an extension project.

This study is justified by the considerable increase in recent years of deaths from preventable diseases in children aged 0 to 11 years throughout Brazil, especially in the most deprived regions where marginalized populations of the health system live. 


\section{METHODOLOGY}

This article is characterized as a descriptive research. For Cervo, Bervian and da Silva (2002) [6], such research methodology occurs when it records, analyzes and correlates facts or phenomena, without manipulating them.

According to Barros and Lehfeld (2000) [7] through descriptive research, it is intended to discover how often a phenomenon occurs, its nature, its characteristics, causes, relationships and connections with other phenomena.

The data obtained are impressions about the reality studied. The way of obtaining the data occurred from the perceptions of the members of the extension project. The collection of such data took place between August and December 2018 at the Instituto de Microbiologia Paulo de Góes - (IMPG-UFRJ). The sample of this research was formed by 10 university students who composed this project in the form of members, with evaluation of actions about a population of 30 children attended by other institutional projects.

The data were recorded in a logbook with the perceptions that occurred in each event. These findings were transcribed to a text editor software (Microsoft Word 2010) so that information analysis could be performed and data cataloguing properly.

This study has limitations in the sense that few meetings were rigorously recorded and subject to data treatment and analysis.

\section{RESULTS AND DISCUSSION}

A didactic game was elaborated by means of pairs of cards that represented certain diseases and their possible causes. During the application of the game, cards representing infectious diseases and cards with unhealthy habits that could lead to the emergence of such diseases were placed. All the content addressed was related to the disciplines studied during the course of Microbiology and Immunology of the institution, however, focused on the education of the community outside the college.

Four groups were formed with six children each. They had ten minutes to establish the relationship they believed to be the most appropriate, from what they knew previously. However, the organization, planning and good execution of the activities were through the active participation of the members of the extension project, in question, so that they could help the children at any time.

The actions were carried out in a classroom of the institution under the supervision of the teacher who coordinated the project, so that, in any needs, she could intervene to properly comply with the work.

As the children performed the activity, they discussed among themselves the possible pairs that would represent the correct answers. There was a greater engagement among the participants, while they were unaware of some practices of unhealthy habits and possible causes of infectious diseases. In these moments, the children paused their activities and tried to figure out some way to solve the case.

At the end of the pre-established time, the children received the answer according to the resulting pairs correctly. Thus, they could didactically correlate their errors and correct answers, also allowing the learning in a playful way to know hygiene practices to avoid infectious diseases.

The didactic games, as long as there is a complete harmony between the playful and educational, are considered as good alternatives adopted by the mediators/teachers that aim to stimulate the student in the construction of knowledge through a spontaneous effort of the learning that is desired. [8]

Felicio and Soares (2018) [9], understand that the mediator of this educational process needs to contribute to the cognitive growth of the child, which when making use of the didactic game, makes the student a reflective and critical being, in search of solutions to problems.

It is important to emphasize the participation of actions in children's collectivity, which, which are oriented under a plan of activities, allows socialization through relaxation, allowing new forms of learning. [10]

Working with games, music, movies, stories, among other games allows new forms of language to be learned by children, in a broad way, stirring with human sensitivity and their ways of acting, thinking and feeling. Activities for children must meet their real needs, meeting them individually and collectively. [11]

It is understood that every space can be adhered to as a formative character, and as one of the goals to be achieved the formation of values and hygiene habits should be consolidated. This strategy is essential for reducing the occurrence of infectious diseases that occur in childhood and that end up compromising the health and well-being of children, thus preventing their full development. [11]

\section{FINAL CONSIDERATIONS}

At the end of the activities, it was noticed that the children were able to establish an adequate relationship about infectious diseases and what practices that represented lack of hygiene that could cause such diseases. While some association of pairs of letters was wrong, they could discover at the end, the correct association and thus correlate to their usual practices, thus contributing to a possible decrease in cases of involvement by infectious diseases associated with the absence of hygiene habits.

Group activities allowed children to socialize, which contributes beyond learning about content, to the development of communication, another primary point for full child development. 
The realization of the extension project contributes to the formation of the future professional biologist, as it allows establishing connections between the academic environment and society, thus promoting significant changes for both sides, especially with regard to self-care practices, socialization, making them more active.

More actions of this type can be encouraged, since they allow extremely relevant gains in the social, political and economic scenario of a region, by being aware that they can reduce the incidence of cases of preventable diseases, leading to the reduction of medical and hospital costs and providing an egalitarian education.

\section{REFERENCES}

[1]. FRANCO, M A S. Práticas pedagógicas de ensinaraprender: por entre resistências e resignações. : por entre resistências e resignações. Educ. Pesqui, São Paulo, v. 41, n. 3, p. 601-614, jul. 2015.

[2]. RUFINO, T C da S. O lúdico na sala de aula: em séries iniciais do ensino fundamental. 2014. 39 f. Monografia (Especialização) - Curso de Fundamentos da Educação, Universidade Estadual da Paraíba, Guarabira, 2014.

[3]. SALCI, M A et al. EDUCAÇÃO EM SAÚDE E SUAS PERSPECTIVAS TEÓRICAS: algumas reflexões. : ALGUMAS REFLEXÕES. Texto Contexto Enferm, Florianópolis, v. 22, n. 1, p. 224 230, mar. 2013.

[4]. MALDINI, G. Falta de higiene básica ameaça saúde. 2019. Elaborada por. Disponível em: https://www.medicina.ufmg.br/falta-de-saneamentobasico-prejudica-diferentes-tipos-de-higiene/. Acesso em: 03 fev. 2020.

[5]. VILELA, M B R; BONFIM, C; MEDEIROS, Z. Mortalidade infantil por doenças infecciosas e parasitárias: reflexo das desigualdades sociais em um município do nordeste do brasil. : reflexo das desigualdades sociais em um município do Nordeste do Brasil. Rev. Bras. Saúde Matern. Infant., Recife, v. 8, n. 4, p. 455-461, out. 2008.

[6]. CERVO, A L; BERVIAN, P A. Metodologia científica. 5.ed. São Paulo: Prentice Hall, 2002.

[7]. BARROS, A J. da S; LEHFELD, $\mathrm{N}$ A. de S. Fundamentos de metodologia cientifica: um guia para a iniciação cientifica. 2 ed. São Paulo: Makron Books, 2000.

[8]. RIBEIRO, M G L.; SANTOS L M F. Atividades Lúdicas No Ensino De Ecologia E Educação Ambiental: Uma Nova Proposta De Ensino. In: Encontro Regional de Ensino de Biologia. Niterói, 2001, Anais..., Niterói, 2001, p. 120-21.

[9]. FELICIO, C M; SOARES, M H F B. Da Intencionalidade à Responsabilidade Lúdica: novos termos para uma reflexão sobre o uso de jogos no ensino de química. : Novos Termos para Uma Reflexão Sobre o Uso de Jogos no Ensino de Química. Química Nova na Escola, [s.1.], p. 1-9, 2018. Sociedade Brasileira de Quimica (SBQ). http://dx.doi.org/10.21577/0104-8899.20160124.
[10]. CHICON, J F; OLIVEIRA, I M de; GAROZZI, G V; COELHO, M F; SÁ, M das G C S de. Brincando e aprendendo: aspectos relacionais da criança com autismo. : aspectos relacionais da criança com autismo. Revista Brasileira de Ciências do Esporte, [s.1.], v. 41, n. 2, p. 169-175, abr. 2019. FapUNIFESP (SciELO). http://dx.doi.org/10.1016/j.rbce.2018.01.017.

[11]. SANTOS, E J (org.). Na Escola também se ensina higiene. 2014. Elaborado por. Disponível em: https://siteantigo.portaleducacao.com.br/conteudo/artig os/nutricao/na-escola-tambem-se-ensinahigiene/56618. Acesso em: 03 fev. 2020.

[12]. PEDROSA, G F S. "The Educational Development of Autistic Students", Volume. 5 Issue. 4, - 2020, International Journal of Innovative Science and Research Technology (IJISRT), www.ijisrt.com. ISSN - 2456-2165, PP :- 327-329.

[13]. PEDROSA, G F S; BARROS, L A A. "The Practice of the Nursing Professional in Child Development", Volume. 5 Issue. 4, - 2020, International Journal of Innovative Science and Research Technology (IJISRT), www.ijisrt.com. ISSN - 2456-2165, PP :681-683. 